\title{
Support of the International Students Studying Earth Sciences at Mining Region University
}

\author{
Oksana Greenwald ${ }^{1,}$, , Anna Resenchuck $^{1}$, and Tatyana Sergeychick ${ }^{1}$ \\ ${ }^{1}$ Kemerovo State University, Institute of Philology, Foreign Languages and Mediacommunications, \\ Department of Foreign Languages, 650000, 6 Krasnaya st., Kemerovo, Russia
}

\begin{abstract}
Being the leading coal mining region in Russia, Kuzbass has significant experience in training specialists in geology, mining industry, ecology and nature management. Therefore, the states-partners of Russia such as Tajikistan, Kirgizia and Uzbekistan are interested in training their specialists for mining industry at Kuzbass universities. In accordance with the Russian state policy for internationalization of Russian higher education it has resulted in sharp increasing of the number of international students at the universities of Kuzbass. A survey of the international students' attitudes carried out at Kemerovo State University, the leading regional university, indicates the necessity to arrange their sociocultural and educational support aimed at their socialization and sociocultural adaptation to the conditions of educational environment of the university. The main principle of sociocultural and educational support of international students is based on the consolidation of different university departments in their organization of educational, scientific, cultural events to create favorable conditions for sociocultural adaptation of international students and their successful achievements in higher education programmes. Moreover, students' intercultural communication promotes business relationships with representatives of the leading coal mining countries.
\end{abstract}

\section{Introduction}

Internationalization as a modern tendency in higher education development in the world is aimed at adjustment of higher education to requirements of globalization in economics and employment market [1]. One of the internationalization trends of Russian higher education is to increase its competitiveness in the global education services market. To implement this idea the federal project «The Strategy for Development of Russian Education Export» has been elaborated. The key items of the project presuppose to make living and educational conditions for international students at Russian universities more comfortable; to arrange educational environment of universities taking into account multicultural and ethnical diversity and to support mutual respect of representatives of different nationalities [2]. International students from 24 countries are provided undergraduate and postgraduate education at the universities of Kuzbass. However, the main amount of international students at Kuzbass universities has come from Central Asia countries of the Commonwealth of

\footnotetext{
* Corresponding author: greenwald.ru@rambler.ru
} 
Independent States, namely, Tajikistan, Kirgizia and Uzbekistan. This is primarily due to the fact that Kuzbass is the leading coal-mining region in Russia. One of the priorities of the region sustainable development is coal mining. Moreover, according to the long-term program for the development of the coal industry in Russia for the period up to 2030, it is planned to increase the annual coal production in Kuzbass by 100 million tons per year [3]. In its turn, coal mining industry is one of the leading ones for the economic development of Central Asia countries. For example, in Tajikistan, coal mining is an intensively developing industry (up to 1.9 million tons in 2018) [4].

The vast experience of training specialists in the field of geology, mining, ecology, environmental management makes it possible to consider Kuzbass universities to be an attractive advanced educational platform not only for coal mining companies of the region, but also for the countries that are Russia's strategic partners in its economic and political development. The state objectives in the field of higher education internationalization and the influx of international students from Tajikistan, Kirgizia, Uzbekistan to Kuzbass universities makes it important to provide proper sociocultural and educational support of international students studying at universities of the region, since it determines the comfortable, tolerant environment for all participants in the educational process through the creation of an adaptive climate and acquiring the culture of a foreign language country.

\section{Materials and methods}

The aim of this research is to determine the effectiveness of sociocultural and educational support of international students conducted at Kemerovo State University, the leading regional university, for their socialization and sociocultural adaptation with respect to their national and cultural identity in the context of the educational process of the university of the coal mining region.

Having analyzed and summarized the opinions of researchers in the field of sociocultural adaptation and educational support [5-8] and taking into account the specifics of our research, we define sociocultural and educational support of international students as the development of social and pedagogical conditions for successful learning, socialization and sociocultural adaptation of international students in the context of educational process of the Russian university in the coal mining region.

The social and pedagogical support of international students at the university is based on the principles of multicultural education, which is a combination of the conditions of university educational environment, promoting the learning of cultures of other ethnic communities, the cultivation of mutual ethnic tolerance, irreconcilability to any form of xenophobia and respect for ethno-cultural pluralism, that is relevant in the modern world, when it becomes necessary to train students and specialists for international cooperation and competition, which will dominate in the new millennium in all spheres of society [9].

The main directions of sociocultural and educational support of international students at the university are diagnostics, psychological, legal or other counseling (individual and group), socio-cultural and ethno-cultural education, an examination of the education content for compliance with the principles of multicultural education and dialogue of cultures.

The listed areas of sociocultural and educational support of international students at Kemerovo State University are implemented by the Center for Intercultural Communications, the psychological service, the Center of Studying Russian Language, curators and deputy directors of educational institutions, teachers.

The relevance and necessity of measures to create sociocultural and educational conditions for international students' support at the university are confirmed by the results of a sociological survey conducted at the beginning and at the end of the 2017-2018 academic year. The participants of the research were 95 international students of the Institute of 
Fundamental Sciences and the Institute of Biology, Ecology and Natural Resources of Kemerovo State University. It should be noted that all students participating in the research are not ethnic Russians: Tajiks are 52 (55\%), Kyrgyz are $22(23 \%)$, Uzbeks are $15(16 \%)$, Turkmen are $2(2 \%)$, and Tatars are $4(4 \%)$. Russian is either a foreign language (34 people or $36 \%$ ) or a school language (61 people or $64 \%$ ) for them.

The sociological survey conducted at the beginning of the 2017-2018 academic year was held in the form of structured interview and questionnaire on a number of issues that are thematically divided into five groups: language, household, intellectual, communicative, and other difficulties and problems experienced by international students who have come to study at Kemerovo State University (see Table 1):

Table 1. The results of sociological survey at the beginning of the 1st academic year.

\begin{tabular}{|c|c|c|}
\hline Problem & Number of students (\%) & $\begin{array}{c}\text { Number of students } \\
\text { (people) }\end{array}$ \\
\hline $\begin{array}{c}\text { 1. Insufficient knowledge } \\
\text { of Russian language }\end{array}$ & $72 \%$ & 68 \\
\hline 2. Household complexity & $68 \%$ & 65 \\
\hline 3. Intellectual difficulties & $56 \%$ & 53 \\
\hline $\begin{array}{c}\text { 4. Communicative } \\
\text { difficulties }\end{array}$ & $32 \%$ & 30 \\
\hline 5. Other & $15 \%$ & 14 \\
\hline
\end{tabular}

As a result of the obtained data analysis, as well as the conversations with international students and teachers, it becomes obvious that insufficient knowledge of Russian as a language of teaching is a significant problem for both parties, since among the teachers there is nobody who can speak the national languages of the students from Central Asia. This problem as the main to impede socialization and training of international students is indicated by other researchers of the problems of international students and labor migrant social adaptation [10].

Every student who comes to study at a university in another city faces the household complexity and the need for social and household adaptation. However, for international students, domestic issues become more compound due to isolation from familiar cultural norms and traditions, in particular with regard to food and cuisine, as well as caused by the climatic features of the host region - many students from Central Asia are unprepared for Siberian weather conditions, they do not have warm clothes and skills to behave properly in the cold climate.

Difficulties associated with intense intellectual work are natural when studying at any university. In addition, international students mainly choose such areas of training as mathematics and computer science, physics, chemistry, and biology that traditionally require constant intellectual tension and understanding of the material being taught from all students. The lack of Russian language competence can significantly complicate or even make impossible the successful acquiring of educational programs in these scientific and educational fields.

The communicative difficulties of international students have several aspects. First of all, the above-mentioned lack of Russian language competence may be the cause of communication failures and fears to communicate with other students and teachers. In rare cases, international students face xenophobia and bias towards them from students and teachers, as well as local residents. Such a situation proves the extreme relevance of the sociocultural education for both the receiving side and the students who have arrived from abroad.

First of all, sociocultural and educational support of international students at the university begins with the efforts of the Center of Studying Russian as a Foreign Language, 
providing international students with necessary Russian language training, which not only leads to the fading away of language difficulties in communication, but also helps to reduce the percentage of students who fail to succeed at the lessons. Moreover, the study of the Russian language provides an opportunity to acquire knowledge about Russian culture, history, literature, contributes to shaping the respect for the culture and laws of the host country and, in general, to establish intercultural dialogue.

As a part of legal counseling for international students, the university organizes visits to the Migration Directorate of the State Ministry of Internal Affairs of the Russian Federation for Kemerovo Region, where they receive detailed information about the rules for obtaining and extending a study visa, migration registration, work permits, temporary residence permits, residence permit and citizenship of the Russian Federation.

The Center for Intercultural Communication of the university is engaged in solving problems of international students in their sociocultural education and sociocultural adaptation. First of all, international students are given excursions around the university and the city of Kemerovo, they are introduced to the city infrastructure, as well as the history and current state of the region of stay - students visit the regional museum of archeology, ethnography and ecology of Siberia, the historical, cultural and natural museum-reserve "Tomskya Pisanitsa", where they get acquainted with the history of Siberia, culture and way of life of the nationalities inhabiting Siberia and Kuzbass.

The Center for Intercultural Communications also organizes the university students' visits to national cultural centers of diasporas living in Kemerovo Region, to familiarize them with the traditions of national cultures and the work of national folk groups. The students of the university speak about the activities of the Center and present their national performances. The social significance of such events entail the development of intercultural dialogue based on the priority values of the cultural identity of all peoples, the strengthening of ties between urban and regional national associations and student art groups.

The Center for Intercultural Communications holds regular events to involve international students in the public activities of the university. When compiling a calendar of events, the Center takes into account national holidays and memorable dates in Russia. For example, the Center organizes the participation of international students in the All-Russian action "Parade of Friendship of the People of Russia" (12th June), the celebration of International Peace Day (21st September), declared by the UN General Assembly as the day of strengthening the ideals of peace among all countries and peoples.

In addition to significant national dates, the Center involves international students in regional, city and university level events - the anniversary of Kemerovo Region (26th January), annual events and the dates of the university "Health Day at the university", "Fair of Student Unions", "Knowledge Day" (1st September), "Fair of National Cultures in the university" (4th November) and others.

In 2018, as part of the celebration of the 75th anniversary of Kemerovo Region, the university hosted the festival "Multinational Kuzbass", where participants and creative teams introduced the student community to the peculiarities of their native culture. In 2019, the festival "Multinational Kuzbass" was held for the second time and is likely to become annual.

In its daily activities, the Center for Intercultural Communications holds weekly meetings to unite students of different nationalities, to help them in socialization, to become involved in the life of the university despite the difference of cultures. All the activities of the Center are aimed at generating interethnic tolerance and attitude to live in peace and harmony with representatives of all nationalities while preserving own cultural identity.

In January 2019, the university, with the assistance of the Education and Science Department of Kemerovo Region Administration, held a seminar on the "Organization of work to foster tolerance and development of positive interethnic relations in educational institutions of higher and professional education of Kemerovo Region”. The holding of such 
events suggests that the issues and problems of the multi-ethnic educational environment of the educational institution are priorities for the regional education authorities.

Along with the cultural and entertainment activities carried out in the framework of extracurricular work, sociocultural and educational support of international students at the university is also provided in the form of arranging educational process. For instance, social and humanitarian subjects have considerable potential for the development of intercultural competence and skills of intercultural communication. In addition, social and humanitarian subjects prevail in the curricula of the first year, when the most intensive activity for sociocultural and educational support of international students is needed.

According with the principles of multicultural education, sociocultural and educational support of international students is based on a personal activity approach, establishing subject-subject relations between participants of the interaction and is implemented in learning situations through interactive educational technologies in order to organize crosscultural interaction in ethnically diverse groups $[11,12]$.

The multicultural education is based on a dialogue of cultures. So, a typical lesson in the social and humanitarian subjects may include a presentation or discussion on the contribution to world science and culture made by nationalities and ethnic groups the international students represent.

Thus, at foreign language lessons in multi-ethnic groups, teachers and professors of the Foreign Languages Department of the Institute of Philology, Foreign Languages and Media Communications of the university actively use such interactive methods as working in ethnically mixed pairs and small groups. Joint activities in fulfilling the assignment in a language that is foreign for all participants contribute to the removal of communication barriers and ethno-cultural stereotypes. Gradually, according to the students' opinion and teachers' observations, students of different nationalities begin to communicate easier and cooperate in the classroom, the effect transferring to extracurricular communication.

Modern educational standards stipulate a large amount of independent students' activity. Project work is one of the forms of independent activity. At foreign language lessons, students from Tajikistan and Kirgizia are given the opportunity to make presentation projects in English about their native city, national education system, traditions, public holidays, linguistic features of their native languages, outstanding scholars and scientific achievements of their country. These presentation projects, without any need to change educational programs, significantly contribute to the sociocultural education of Russian students regarding the cultural and national characteristics of their international fellow students that results in complete decline in the incidents involving prejudice, xenophobia and aggressive nationalism in students' environment.

The Center for Intercultural Communications of the university also promotes scientific knowledge and the development of international students' interest in scientific activities. The Center organizes such events as the annual inter-ethnic intellectual game "Our Unity", training on "Targeting" and "Leadership", master classes, for example, "How to build a successful career from the 1st year", which are aimed at mobilizing the intellectual potential of students, to stimulate their intellectual activity.

A special part is played by the master class of the university students-participants of the international volunteer program "Ambassadors of the Russian language in the world", initiated by the State Russian Language Institute named after A. S. Pushkin. Such work, on the one hand, is aimed at popularizing the Russian language, culture and literature in the world, and on the other hand, it promotes language adaptation of international students at the university by improving their Russian language. This is confirmed by the fact that in 2018 international students of the university took part at the VIII International Pushkin Competition "What is my name to you?" 
In 2018, the project "Erasing All Borders" started in the university. Its purpose is to form a basis for interaction between students and representatives of national diasporas of the region. Within the framework of the project, participants attended master classes and open lectures, as well as took part in the preparation of a multicultural forum event aimed at strengthening civil self-awareness and harmonizing inter-ethnic relations.

\section{Results and discussion}

The second stage of the sociological survey of the sociocultural and educational support effectiveness for international students was conducted at the end of the 2017-2018 academic year and showed a decrease in the number of students who indicated the occurrence of language, household, communicative, intellectual and other problems (Table 2).

Table 2. The results of sociological survey at the end of the 1st academic year.

\begin{tabular}{|c|c|c|c|}
\hline Problem & $\begin{array}{c}\text { Number of } \\
\text { students (\%) }\end{array}$ & $\begin{array}{c}\text { Number of } \\
\text { students } \\
\text { (people) }\end{array}$ & $\begin{array}{c}\text { Difference relative to } \\
\text { the first measurement }\end{array}$ \\
\hline $\begin{array}{c}\text { 1. Insufficient } \\
\text { knowledge of Russian } \\
\text { language }\end{array}$ & 22 & 24 & $-50 \%$ (-44 people) \\
\hline $\begin{array}{c}\text { 2. Household } \\
\text { complexity }\end{array}$ & 25 & 26 & $-43 \%$ (-39 people) \\
\hline $\begin{array}{c}\text { 3. Intellectual } \\
\text { difficulties }\end{array}$ & 47 & 45 & $-9 \%$ (-8 people) \\
\hline $\begin{array}{c}\text { 4.Communicative } \\
\text { difficulties }\end{array}$ & 11 & 12 & $-21 \%$ (-18 people) \\
\hline 5. Other & 9 & 10 & $-6 \%(-4$ people) \\
\hline
\end{tabular}

The intensive work of the Center for the Study of the Russian Language and the constant immersion into the language environment contribute to the advance in the knowledge of the Russian language by international students. The lack of Russian language knowledge as the main problem at the end of the 1 st academic year is indicated by $22 \%$ of international students ( 24 respondents), which is $50 \%$ (44 respondents) less than at the beginning of the academic year.

The decrease in the number of international students who indicated that they experience household complexity by $43 \%$ to 26 respondents is due to the efforts of the university administration to accommodate international students in more comfortable dormitories on the territory of the campus, as well as familiarity with the city's infrastructure, comprehensive assistance and support of national diasporas and adaptation to local climatic conditions.

The increased level of proficiency in Russian as a language of teaching and adaptation to the conditions of study contribute, though slightly, to a decrease in the number of international students who indicated intellectual difficulties in learning by $9 \%$ to 45 respondents. This fact is confirmed by a slight increase (by 5\%) in the quality performance of international students as a result of the summer session at the end of the 2nd semester as compared with the results of the winter session at the end of the 1 st semester.

Communicative difficulties, such as the fear of starting communication with Russian students and teachers, failures and misunderstanding in communication, manifestations of prejudice, were indicated by 18 people $(21 \%)$ less. 


\section{Conclusion}

To sum up, consolidation of educational, scientific, cultural events has become the main principle of organizing sociocultural and educational support of international students at Kemerovo State University. The results of sociological survey allow us to conclude that sociocultural and educational support measures promote intercultural dialogue; create favorable conditions for sociocultural adaptation and successful mastering of higher education programs for international students from Central Asia who study at Kemerovo State University. Moreover, at the university international students can successfully master English that is the official language of the USA, Australia and South Africa, which are in the top 10 countries leading in coal mining. This knowledge will help international graduates from Central Asia to do a successful business in the international level with representatives of the countries - the leaders in coal mining industry.

\section{References}

1. H. De Wit, Centre for Applied Research on Economics \& Management (School of Economics and Management of the Hogeschool van Amsterdam, Amsterdam, 2011)

2. The Strategy for Development of Russian Education Export (MSE, Moscow, 2018)

3. The long-term programme of the coal sector development in Russia till 2030 (ASI, Moscow, 2018)

4. Tajikistan - Mining Equipment and Services (TSJK, Dushanbe, 2017)

5. Z.A. Latipov, Revista ESPACIOS, 38, 27 (2017)

6. V.T. Pavlushkina, International Review of Management and Marketing, 6, 69-75 (2016)

7. J. Lee, A. Ciftci, Int. J. Intercul. Rel., 38, 97-105 (2014)

8. G.P. Wilson, NERA Conference Proceedings, 21, 00210 (2011)

9. A.N. Dzhurinsky, Procedia - Social and Behavioral Sciences, 186, 811-814 (2015)

10. W. Searle, Int. J. Intercul. Rel., 14, 449-464 (1990)

11. T. N. Ng, K. W. C. Wang, W. Chan, Int. J. Intercul. Rel., 59, 19-30 (2017)

12. C. R. Glass, E. Gómez, A. Urzua, Int. J. Intercul. Rel., 42, 104-117 (2014) 